\title{
ANALISIS KADAR KLOROFIL PADA BUNCIS (Phaseolus vulgaris L.) TERINDUKSI INDOLE ACETIC ACID (IAA) SECARA IN VITRO
}

\author{
Endang Nurcahyani ${ }^{1}$, Desti Deria Rahmadani ${ }^{2}$, Sri Wahyuningsih ${ }^{2}$, Mahfut ${ }^{1}$ \\ ${ }^{1}$ Program Studi Biologi Terapan, Jurusan Biologi, FMIPA, Universitas Lampung \\ ${ }^{2}$ Program Studi Biologi, Jurusan Biologi, FMIPA, Universitas Lampung
}

\author{
endang.nurcahyani@fmipa.unila.ac.id
}

\begin{tabular}{|l|}
\hline Artikel Info \\
Diterima \\
tanggal \\
12.11 .2019 \\
Disetujui \\
publikasi \\
tanggal \\
30.04 .2020 \\
\\
Kata kunci : \\
Indole Acetic \\
Acid, in vitro, \\
Klorofil, \\
Pertumbuhan, Ph \\
aseolus \\
vulgaris L.
\end{tabular}

\section{ABSTRAK}

Buncis (Phaseolus vulgaris L.) adalah salah satu komoditas pangan yang memiliki sumber protein dan aman dikonsumsi.Seiring dengan berjalannya waktu dan perubahan iklim yang tidak menentu, para petani sayuran termasuk Buncis kesulitan dalam memproduksi hasil pertanian dengan baik, sehingga menyebabkan produksi tanaman buncis menurun. Indole Acetic Acid (IAA) merupakan hormon auksin yang terdapat pada ujung akar, batang dan pembentukan bunga. Hormon auksin IAA dapat memicu percepatan pertumbuhan pada akar, batang dan perkembangan bunga. Penelitian ini bertujuan untuk mengetahui efek pemberian IAA pada jumlah planlet hidup dan kadar klorofil a, b dan total planlet buncis (Phaseolus vulgaris L.) secara in vitro. Penelitian ini menggunakan Rancangan Acak Lengkap dengan variasi konsentrasi Indole Acetic Acid yang terdiri dari 4 taraf perlakuan yaitu $0 \mathrm{ppm}, 0,5$ ppm, $1 \mathrm{ppm}$, dan 1,5 ppm. Masing masing konsentrasi dilakukan 5 kali pengulangan dan setiap pengulangan terdiri dari 3 eksplan biji buncis dalam setiap botol kultur. Data dianalisis dengan menggunakan Uji homogenitas dan Uji Lanjut Beda Nyata Terkecil (BNT) pada taraf nyata 5\%. Hasil penelitian menunjukkan bahwa persentase planlet hidup menunjukkan $100 \%$ hidup dan pemberian IAA memberikan pengaruh terhadap kadar klorofil a dan total secara in vitro.

\section{ABSTRACT}

Beans (Phaseolus vulgaris L.) is a food commodity that has a protein source and is safe for consumption. As time goes by and climate change is uncertain, vegetable farmers, including beans, have difficulty in producing agricultural products properly, causing the production of beans to decrease. Indole Acetic Acid (IAA) is an auxin hormone found at the tips of roots, stems and flower formation. IAA auxin hormone can trigger the acceleration of growth in roots, stems and flower development. This study aims to determine the effect of IAA administration on the number of live plantlets and levels of chlorophyll $a, b$ and total plantlets of beans (Phaseolus vulgaris L.) in vitro. This study uses a Completely Randomized Design with variations in the concentration of Indole Acetic Acid which consists of 4 levels of treatment namely 0 ppm, 0.5 ppm, 1 ppm, and 1.5 ppm. Each concentration was repeated 5 times and each repetition consisted of 3 explants of bean seeds in each culture bottle. Data were analyzed using the Homogeneity Test and the Least Significant Difference Test (LSD) at the 5\% significance level. The results showed that the percentage of live plantlets showed 100\% life and the provision of IAA had an influence on chlorophyll a and total levels in vitro.

doi: http://dx.doi.org/10.23960/aec.v5.i1.2020.p15-23

Anal.Environ.Chem. 


\section{PENDAHULUAN}

Peningkatan produktivitas buncis dapat dilakukan dengan cara teknik kultur jaringan yang menghasilkan tanaman dalam jumlah besar dalam waktu yang singkat, tidak bergantung pada iklim, serta kesehatan tanaman. Teknik kultur jaringan memerlukan zat pengatur tumbuh (ZPT) seperti sitokinin dan auksin. Zat pengatur tumbuh yang berfungsi untuk pertumbuhan tanaman maupun pembentukan anakan serta perpanjangan akar tergolong kedalam kelompok auksin, diantaranya Indole Acetic Acid (IAA). Jenis dan konsentrasi ZPT tergantung pada tujuan dan tahap pengkulturan (Ali et al., 2007).

Klorofil yaitu pigmen utama pada tanaman. Pada umumnya terdapat dua jenis klorofil pada tanaman tingkat tinggi yaitu klorofil a dan klorofil b (Ai dan Banyo, 2011). Pigmen klorofil dapat menyerap lebih banyak cahaya berwarna biru $(400-450 \mathrm{~nm})$ dan merah $(650-700 \mathrm{~nm})$ dibandingkan hijau (500-600 nm). Tumbuhan dapat memperoleh kebutuhan energy dari spectrum merah dan biru yaitu antara 500-600 nm. Jadi warna hijau pada daun disebabkan karena klorofil menyerap cahaya merah dan biru dan meneruskan dan memantulkan cahaya hijau (Poruka, 2004).

Kandungan klorofil pada daun bervariasi dari satu jenis tanaman dengan tanaman lainnya. Selain umur dan varietas daun, kandungan klorofil juga bervariasi dilihat dari posisi daun dalam satu tanaman (Mustafa et al., 2015). Fotosintesis, yang terjadi di daun membutuhkan dua bahan utama yaitu $\mathrm{CO}_{2}$ dan $\mathrm{H}_{2} \mathrm{O}$. Reaksi utama fotosintesis terjadi di kloroplas dengan agen utamanya yakni klorofil. Pembentukan klorofil pada daun paling banyak dipengaruhi oleh cahaya matahari, namun umur daun juga mempengaruhi kadar klorofil yang terdapat pada suatu daun. Padahal pada awal perkembangan daun, aktivitas meristem daun menyebabkan terjadinya perpanjangan daun. Perpanjangan daun berikutnya terjadi sebagai akibat aktivitas meristem interkalar (Hidayat, 2008), berarti agian pangkal daun seharusnya lebih tua dibanding ujung daun yang berakibat juga pada klorofil yang dikandungnya. Pada tumbuhan tingkat tinggi, klorofil a dan klorofil b merupakan pigmen utama fotosintetik, yang berperan menyerap cahaya violet, biru, merah dan memantulkan cahaya hijau (Salaki, 2000).

Kandungan klorofil pada daun akan mempengaruhi reaksi fotosintesis. Kadar klorofil yang sedikit tentu tidak akan menjadikan reaksi fotosintesis maksimal. Ketika reaksi fotosintesis

doi: http://dx.doi.org/10.23960/aec.v5.i1.2020.p15-23

Anal.Environ.Chem. 
tidak maksimal, senyawa karbohidrat yang dihasilkan juga tidak bisa maksimal. Yohanis (2009) menyatakan pada tumbuhan karbohidrat terdapat selulosa, yaitu senyawa yang membentuk dinding sel tumbuhan. Serat kapas dapat dikatakan seluruhnya terdiri atas selulosa. Penelitian yang berhubungan dengan tanaman buncis pernah diteliti oleh Nurcahyani dkk. (2019) dan dianalisis mengenai kandungan karbohidrat terlarut totalnya, dengan menggunakan metode fenol-sulfir secara in vitro. Pada penelitian ini diteliti tentang kandungan korofil tanaman buncis setelah diinduksi dengan IAA secara in vitro.

\section{METODE}

\section{Alat dan Bahan}

Alat dan bahan yang digunakan dalam penelitian adalah autoclave, Laminar Air Flow (LAF), spektrofotometer, oven, botol kultur, cawan petri, tabung reaksi, rak tabung reaksi, gelas ukur bervolume $10 \mathrm{ml}$, Erlenmeyer, Beaker glass, $\mathrm{pH}$ meter, bunsen, batang pengaduk, mortar dan pastel, panci, kompor, timbangan analitik, Ohaus, pinset, tisu steril, hand sprayer, alat tulis, plastic wrap, aluminium foil dan kertas label .biji buncis (Phaseolus vulgaris L.), alkohol 70\% dan 96\% untuk sterilisasi alat sukrosa, agar-agar, Kalium Hidroksida $(\mathrm{KOH})$, Asam Chlorida ( $\mathrm{HCl}$, akuades, Indole Acetic Acid, bahan dasar medium Murashige and Skoog (MS) medium yang digunakan untuk penanaman eksplan, agar-agar, larutan stok organik yaitu vitamin, sukrosa, asam amino, dan baycline (digunakan untuk sterilisasi eksplan).

\section{Prosedur}

Medium yang digunakan dalam penelitian ini yaitu Murashige \& Skoog (MS) "use ready". Cara pembuatan medium tanam MS 1 liter yaitu dengan medium dasar Murashige \& Skoog (MS) "use ready" sebanyak 4,43g ditimbang, lalu dimasukkan ke dalam beaker glass 1 liter. Setelah itu ditambahkan akuades sampai 1 liter sesuai batas pada beakser glass, lalu dilarutkan. Setelah itu diukur $\mathrm{pH}$ larutan sampai 5,5. Jika pH terlalu basa ditambahkan HCL $1 \mathrm{~N}$, jika pH terlalu asam maka ditambahkan $\mathrm{KOH} 1 \mathrm{~N}$.

Setelah di ukur ph lalu medium dipindahkan ke dalam panci dan ditambah agar-agar sebanyak $7 \mathrm{~g} / \mathrm{l}$ dan sukrosa 30g/l. Selanjutnya larutan medium dipanaskan sampai mendidih di

doi: http://dx.doi.org/10.23960/aec.v5.i1.2020.p15-23

Anal.Environ.Chem. 
atas kompor sambil diaduk untuk melarutkan agar-agar dan sukrosa, kemudian dituangkan ke dalam botol kultur sebanyak $20 \mathrm{ml} /$ botol. Lalu di tetesi ditetesi Indole Acetic Acid dengan taraf konsentrasi 0 ppm, 0,5 ppm, 1 ppm dan 1,5 ppm. Setelah itu medium disterilisasi menggunakan autoclave pada tekanan $1 \mathrm{~atm}$ dan suhu $121^{\circ} \mathrm{C}$ selama 15 menit.

Setelah medium disterilisasi, medium di inkubasi selama 1 minggu pada suhu kamar (25 ${ }^{\circ} \mathrm{C}$ ) untuk memastikan tidak terjadi kontaminasi pada medium tanam, sehingga medium siap digunakan, setelah 1 minggu medium dibawa ke Laminar Air Flow untuk ditanam biji buncis.Sterilisasi Eksplan berupa biji buncis direndam dalam akuades steril selama 15 menit. Setelah itu biji direndam dengan bayclean $10 \%$ selama 5 menit. Setelah itu biji dibilas dengan akuades steril selama 5 menit dan dilakukan sebanyak 3 kali. Semua kegiatan ini dilakukan dalam ruang steril di dalam Laminar Air Flow (LAF). Penanaman biji buncis dilakukan dalam Laminar Air Flow (LAF), setiap botol kultur ditanami 3 biji buncis sehingga total biji buncis yaitu 60 biji dalam 20 botol kultur. Biji buncis lalu ditumbuhkan menjadi planlet.

Analisis kandungan klorofil dilakukan pada hari terakhir pengamatan. Penentu kandungan klorofil dilakukan menurut Miazek (2002), bahan analisis klorofil menggunakan daun planlet buncis yang sudah diberi Indole Acetic Acid dengan menggunakan Spektrofotometer. Analisis kandungan klorofil dapat dilakukan dengan cara mengambil daun planlet buncis yang sama sebanyak 0,1 g lalu dihilangkan tulang daunnya, kemudian dihaluskan dengan mortar dan ditambahkan alkohol. Setelah itu larutan disaring dengan kertas saring dan dimasukkan ke dalam flakon lalu ditutup rapat. Larutan sampel dan larutan standar (alkohol) diambil sebanyak $1 \mathrm{ml}$ dimasukkan dalam kuvet. Setelah itu dilakukan pembacaan serapan dengan spektrofotometer UV pada panjang gelombang ( $\lambda$ ) $648 \mathrm{~nm}$ dan $664 \mathrm{~nm}$ dengan 3 kali ulangan setiap sampel.

\section{HASIL DAN PEMBAHASAN}

\section{Persentase Jumlah Planlet Hidup}

Pada pengamatan persentase planlet hidup buncis (Phaseolus vulgaris L.) dengan perlakuan Zat Pengatur Tumbuh (ZPT) Indole Acetic Acid (IAA) secara in vitro menunjukkan pertumbuhan yang sangat baik pada minggu ke 2 sampai dengan minggu ke 4. Eksplan tersebut membutuhkan waktu rata-rata dua minggu setelah tanam (MST) untuk merespon nutrisi yang

doi: http://dx.doi.org/10.23960/aec.v5.i1.2020.p15-23

Anal.Environ.Chem. 
terdapat pada medium tanam. Persentase planlet hidup buncis (Phaseolus vulgaris L.) pada minggu ke-4 disajikan pada Tabel. 1.

Berdasarkan Tabel 1 diketahui bahwa hasil persentase jumlah planlet hidup selama 4 minggu setelah tanam pada perlakuan IAA menunjukkan hasil 100\% planlet hidup, yang berarti bahwa hasilnya tidak berbeda pada setiap perlakuan selama 4 minggu setelah tanam. Pada kultur jaringan, medium Murashige and Skoog (MS) yaitu medium dasar yang digunakan untuk penanaman planlet atau eksplan. Medium MS memiliki komposisi yang dapat memenuhi kebutuhan nutrisi untuk banyak jenis tumbuhan karena mengandung unsur hara makro dan mikro, sumber energi, serta vitamin (Gunawan dan Azhari, 2010).

Pertumbuhan eksplan buncis (Phaseolus vulgaris L.) diberikan perlakuan IAA dengan berbagai konsentrasi menunjukkan respon yang baik terhadap parameter persentase jumlah planlet hidup, jumlah daun dan tinggi tanaman. Pada jumlah planlet hidup, ciri-ciri yang ditunjukkan pada pertumbuhan planlet yang hidup dapat dilihat dari jumlah daun, jumlah tunas dan akar yang tumbuh.

Tabel 1. Persentase Jumlah Planlet Hidup Buncis (Phaseolus vulgaris L.) secara in vitro.

\begin{tabular}{|c|c|c|c|c|}
\hline \multirow{2}{*}{$\begin{array}{l}\text { Perlakuan IAA } \\
\qquad(\mathbf{p p m})\end{array}$} & \multicolumn{4}{|c|}{$\begin{array}{c}\text { Persentase Jumlah Planlet Hidup pada } \\
\text { Minggu }(\%)\end{array}$} \\
\hline & I & II & III & IV \\
\hline $0 \mathrm{ppm}$ & 100 & 100 & 100 & 100 \\
\hline $0,5 \mathrm{ppm}$ & 100 & 100 & 100 & 100 \\
\hline $1 \mathrm{ppm}$ & 100 & 100 & 100 & 100 \\
\hline $1,5 \mathrm{ppm}$ & 100 & 100 & 100 & 100 \\
\hline
\end{tabular}

Keterangan: Angka 100\% menandakan bahwa planlet hidup dari minggu ke-1 sampai minggu ke-5 .

doi: http://dx.doi.org/10.23960/aec.v5.i1.2020.p15-23 Anal.Environ.Chem. 


\section{Kadar Klorofil.}

\section{a. Kadar Klorofil a.}

Kandungan klorofil a pada daun buncis yang diberi perlakuan penambahan IAA dengan berbagai konsentrasi disajikan pada Tabel 2. Berdasarkan Tabel 2. Analisis ragam pada taraf nyata 5\% menunjukkan bahwa interaksi hormon auksin IAA terhadap kandungan klorofil a pada planlet buncis memberikan hasil yang berbeda nyata[p-value $0,005>0,05]$. Berdasarkan Tabel 2 menunjukkan bahwa konsentrasi 0 ppm berpengaruh nyata dengan nilai tertinggi 6,98. Hal ini diduga pada konsentrasi 0 ppm pada medium MS tanpa penambahan IAA sudah memiliki kandungan nutrisi yang cukup bagi kandungan klorofil a. Medium MS memiliki kandungan meliputi nitrat, kalium dan ammonium yang tinggi, serta kandungan unsur hara anorganik yang cukup seperti $\mathrm{N}, \mathrm{Mg}$ dan Fe sebagai pembentuk dan katalis dalam sintesis protein (Subandi, 2008; Yuliarti, 2010).

Tabel 2. Rata-rata kandungan klorofil a planlet buncis (Phaseolus vulgaris L.)

\begin{tabular}{cc}
\hline Konsentrasi IAA $(\mathbf{p p m})$ & Klorofil a. \\
\hline 0 & $6,98 \pm 0,57^{\mathrm{a}}$ \\
0,5 & $4,60 \pm 1,63^{\mathrm{b}}$ \\
1 & $3,30 \pm 0,60^{\mathrm{b}}$ \\
1,5 & $3,18 \pm 0,41^{\mathrm{b}}$ \\
\hline
\end{tabular}

\section{Keterangan:}

Klorofil $a=\bar{Y} \pm S E$

$\bar{Y}=$ rata-rata klorofil a tanaman

$S E=$ standar error

Angka yang diikuti huruf yang sama menunjukkan hasil yang tidak berbeda nyata.

\section{b. Kadar Klorofil b}

Kandungan klorofil b pada daun buncis yang diberi perlakuan penambahan hormon auksin IAA dengan berbagai konsentrasi disajikan pada Tabel 3.

doi: http://dx.doi.org/10.23960/aec.v5.i1.2020.p15-23 
Tabel 3. Rata-rata kandungan klorofil b planlet buncis (Phaseolus vulgaris L.)

\begin{tabular}{|c|c|}
\hline Konsentrasi IAA (ppm) & Klorofil b. \\
\hline 0 & $3,31 \pm 0,30$ \\
\hline 0,5 & $3,25 \pm 0,78$ \\
\hline 1 & $1,74 \pm 0,19$ \\
\hline 1,5 & $3,74 \pm 1,29$ \\
\hline
\end{tabular}

Homogenitas ragam menggunakan uji levene pada taraf 5\% menunjukkan bahwa interaksi hormon auksin IAA terhadap kandungan klorofil b yaitu tidak homogen. Setelah dilakukan uji statistik analisis varians menunjukkan hasil yang tidak berbeda nyaa [p-value0,321>0,05] terhadap kandungan klorofil b planlet buncis. Hal ini diduga karena konsentrasi IAA yang diberikan tidak sesuai maka menghambat produksi kandungan klorofil b. Berdasarkan hasil analisis menunjukkan bahwa penggunaan medium MS dengan penambahan IAA dengan konsentrasi yang cukup dapat meningkatkan kandungan klorofil b pada planlet buncis.

\section{c. Kadar Klorofil Total \\ d.}

Tabel 4. Rata-rata kandungan klorofil total planlet buncis (Phaseolus vulgaris L.)

\begin{tabular}{|c|c|}
\hline Konsentrasi IAA (ppm) & Klorofil Total. \\
\hline 0 & $16,72 \pm 1,39^{a}$ \\
\hline 0,5 & $12,28 \pm 1,78^{\mathrm{ab}}$ \\
\hline 1 & $8,12 \pm 1,35^{\mathrm{b}}$ \\
\hline 1,5 & $10,21 \pm 1,65^{\mathrm{b}}$ \\
\hline
\end{tabular}

doi: http://dx.doi.org/10.23960/aec.v5.i1.2020.p15-23

Anal.Environ.Chem. 
Kandungan klorofil $\mathrm{b}$ pada daun buncis yang diberi perlakuan penambahan hormon auksin IAA dengan berbagai konsentrasi disajikan pada Tabel 4. Homogenitas ragam menggunakan uji levene pada taraf 5\% menunjukkan bahwa interaksi hormon auksin IAA terhadap kandungan klorofil totalyaitu homogen. Berdasarkan Tabel 4uji statistik analisis varian memberikan hasil yang berbeda nyata [p-value $0,008<0,05$ ] yang artinya penambahan IAA ke dalam medium MSterdapat perbedaan yang nyata dari parameter kandungan klorofil total tersebut.

\section{KESIMPULAN}

Berdasarkan penelitian yang telah dilakukan dapat disimpulkan bahwa pemberian IAA pada jumlah planlet yang hidup memberikan hasil 100\% hidup. Pada kandungan klorofil a dan total yang telah diinduksi IAA memberikan hasil yang berbeda nyata dibandingkan dengan kontrol.

\section{DAFTAR PUSTAKA}

Ali S. K., Elhassan A. A., Ehiwaris, O. S.,Maki, E. H. 2007. Regeneration Viaimmature Mak Flower Culture of Banana (Musa sp) cv. Grand Nain. Journal of forest products \& Indutries. 2 (3) : 48-52.

Ai dan Banyo. 2011. Konsentrasi Klorofil Daun Sebagai Indikator Kekurangan Air Pada Tanaman. Jurnal Ilmiah Sains Vol. 11 No. 2.

Gunawan, B. dan Azhari, C. D. 2010. Karakterisasi Spektofotometri dan Scaning Electron Microcopy (SEM) Sensor Gas dari Bahan Polimer Poly-Etilene Glycol (PEG).Jurnal science:1979-6870.

Hidayat, E. B. 2008. Anatomi Tumbuhan. Penerbit ITB. Bandung, Indonesia

Miazek K. 2002. Chlorophyll Extraction From Harvested Plant Material. Supervisor. Ha. Inz. Stainslaw Lekadowicz

Mustafa, N. N. Ya'acob., Z. A. Latif., and A. L. Yusof. 2015. Quantification of oil palm tree leaf pigment (Chlorophyll A) concetration Based on Their Age. Jurnal Teknologi. 75:129-134.

Nurcahyani, E. Mutmainah, A. N., Farisi. S., Agustrina, R. 2019. Analisis Kandungan Karbohidrat Terlarut Total Planlet Buncis (Phaseolus vulgaris L.) Menggunakan Metode Fenol-Sulfur Secara In Vitro. Analit: Analytical and Environmental Chemistry. 4(1):73-80.

doi: http://dx.doi.org/10.23960/aec.v5.i1.2020.p15-23

Anal.Environ.Chem. 
Poruka. 2004. Chlorophyll. http://www.biologie.uni-hamburg.de/b-online/e24/3.htm. Diakses pada 11 oktober 2018 pukul 15:05 WIB.

Salaki, M. 2000. Biologi Sel. Proyek Pengembangan Perguruan Tinggi Indonesia Development Agency Simon Fraset University.

Sartika, Y., Nurbaity, A., Sofyan, E. 2008. Efek Sterilisasi dan Komposisi Media Inokulan Konsorsium Mikoriza Arbuskular dan Mycrrhizal helper bacteria Terhadap Jumlah Spora MA, Populasi MHB, dan Nisbah Pupus Akar Sorgum. Agric Sci Jurnal. 1(4):262-268.

Subandi, A. 2008. Metabolisme. Retrieved from http://metabolisme.blogspot.com. Diakses pada tanggal 11 oktober 2019 pukul 19:00 WIB.

Yuliarti, N. 2010. Kultur Jaringan Tanaman Skala Rumah Tangga. Lily Publisher. Yogyakarta.

Yohanis, N. 2009. Biokimia: Struktur dan Fungsi Biomolekul. Graha Ilmu. Yogyakarta.

doi: http://dx.doi.org/10.23960/aec.v5.i1.2020.p15-23

Anal.Environ.Chem. 